\begin{tabular}{cc|c}
\hline Tar. Bil. Der. & Journal of Agricultural Sciences \\
& $\begin{array}{c}\text { Dergi web sayfası: } \\
\text { www.agri.ankara.edu.tr/dergi }\end{array}$ & Journal homepage: \\
& www.agri.ankara.edu.tr/journal
\end{tabular}

\title{
Determination of Size Selectivity of Traps for Blue Crab (Callinectes sapidus Rathbun, 1896) in the Mediterranean Sea
}

\author{
Süleyman ÖZDEMİR ${ }^{\mathrm{a}}$, Gökhan GÖKÇE ${ }^{\mathrm{b}}$, Mustafa ÇEKIÇ⿻

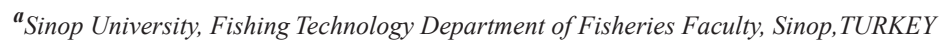 \\ ${ }^{b}$ Çukurova University, Fishing Technology Department of Fisheries Faculty, Adana,TURKEY \\ ${ }^{c}$ Çukurova University, Fisheries Division of Yumurtalık Vocational School, Adana, TURKEY
}

\section{ARTICLE INFO}

Research Article

DOI: $10.1501 /$ Tarimbil_0000001327

Corresponding Author: Süleyman ÖZDEMIR, E-mail: suleymanozdemir57@yahoo.com, Tel: +90 (368) 2715728

Received:17 December 2013, Received in Revised Form: 10 June 2014, Accepted: 30 June 2014

\begin{abstract}
This study investigates the effects of trap selectivity of various mesh size on escape success of the blue crab (Callinectes sapidus). The study was carried out Çamlık Lagoon of Yumurtalık Gulf in the Mediterranean Sea and total of 1051 blue crabs were caught by rectangular baited trap. Using traps constructed with 30, 35, 40, 45 and $50 \mathrm{~mm}$ square mesh the proportion of crabs escaping through each mesh size was measured for each half centimetre carapace width (CW) class. A logistic model was fitted to the size frequency data of the retained and escaped blue crabs for each mesh size in the experiment. $\mathrm{L}_{50}$ and selection range (SR) for the $30,35,40,45$ and $50 \mathrm{~mm}$ (bar length) square meshes tested in this study was $8.47 \mathrm{~cm}$ and $0.85 \mathrm{~cm} ; 9.31 \mathrm{~cm}$ and $0.39 \mathrm{~cm} ; 10.40 \mathrm{~cm}$ and $0.31 \mathrm{~cm} ; 11.72 \mathrm{~cm}$ and $1.17 \mathrm{~cm} ; 13.17 \mathrm{~cm}$ and $0.89 \mathrm{~cm}$ respectively. The $50 \mathrm{~mm}$ square mesh of the trap showed relatively better selectivity considering the size at $50 \%$ sexual maturity of blue crab Callinectes sapidus, and the high rate of immature escapers.
\end{abstract}

Keywords: Blue crab Callinectes sapidus; Trap; Size selectivity; Mediterranean Sea

\section{Akdenizde Mavi Yengeç (Callinectes sapidus Rathbun, 1896) Tuzaklarının Boy Seçiciliğinin Belirlenmesi}

\section{ESER BILGISII}

Araştırma Makalesi

Sorumlu Yazar: Süleyman ÖZDEMİ, E-posta: suleymanozdemir57@yahoo.com, Tel: +90 (368) 2715728

Geliş Tarihi: 17 Aralık 2013, Düzeltmelerin Gelişi: 10 Haziran 2014, Kabul: 30 Haziran 2014

\section{ÖZET}

$\mathrm{Bu}$ çalışmada mavi yengeç (Callinectes sapidus)'in tuzaktan kaçma başarısı üzerinde çeşitli göz açıklığına sahip tuzakların seçicilik etkileri incelenmiştir. Araştırma Akdeniz'de Yumurtalık körfezi, Çamlık Lagününde yürütülmüş dikdörtgen şekilli yemli tuzaklar kullanılarak toplam 1051 adet mavi yengeç yakalanmıştır. 30, 35, 40, 45 ve 50 mm kare gözlü ağ ile donatılmış tuzaklarla her bir tuzaktan kaçan yengeçlerin oranı $0.5 \mathrm{~cm}$ lik karapaks genişlik (CW) sınıfında ölçülerek tespit edilmiştir. Denemede her göz açıklığı için tuzaklarda kalan ve kaçan mavi yengeçlerin boy frekans 
verilerine göre lojistik bir model kullanılmıştır. Araştırmada kullanılan 30, 35, 40, 45 ve 50 mm'lik kare gözlü ağların \% 50 seçicilik boyu $\left(\mathrm{L}_{50}\right)$ ve seçicilik aralığ $(\mathrm{SR})$ sirasiyla $8.47 \mathrm{~cm}$ ve $0.85 \mathrm{~cm} ; 9.31 \mathrm{~cm}$ ve $0.39 \mathrm{~cm} ; 10.40 \mathrm{~cm}$ ve 0.31 $\mathrm{cm} ; 11.72 \mathrm{~cm}$ ve $1.17 \mathrm{~cm} ; 13.17 \mathrm{~cm}$ ve $0.89 \mathrm{~cm}$ olarak belirlenmiştir. Tuzaktan kaçan ergin olmayan mavi yengeçlerin yüksek oranı ve \% 50 cinsi olgunluk boyu dikkate alındığında 50 mm'lik kare gözlü ağa sahip tuzak, diğer tuzaklara göre daha yüksek seçicilik göstermiştir.

Anahtar Kelimeler: Mavi yengeç Callinectes sapidus; Tuzak; Boy seçiciliği; Akdeniz

(C) Ankara Üniversitesi Ziraat Fakültesi

\section{Introduction}

The blue crab is an important commercial species that inhabits coastal areas, estuaries, and lagoons throughout the southern part of Turkey (Enzenross et al 1997; Türeli 1999). The maximum Carapace Width (CW) of blue crab reported in Turkey is 18.1 $\mathrm{cm}$ and mean $\mathrm{CW}$ is $12 \mathrm{~cm}$ for both female and male crabs (Türeli 1999; Atar \& Seçer 2003). Reported size at first maturity is $6.05 \mathrm{~cm}$ for female and 4.48 $\mathrm{cm}$ for male individuals (Türeli 1999). Hexagonal or square mesh wire traps with a small mesh size are currently used by commercial fishermen to catch blue crabs in Turkish lagoons. In Turkish fishery regulations, there is a Minimum Landing Size (MLS) of $13 \mathrm{~cm} \mathrm{CW}$ with a $5 \%$ tolerance of smaller individuals for the blue crab (TFG 2012). However, there is no required mesh shape, nor a minimum mesh size limit for traps, which constitute the most commonly, used fishing gear in crab fisheries. Mesh size selection is crucial, because it determines the size composition of catch and consequently, the sub-legal to legal ratio (Guillory \& Prejean 1997). Unacceptable numbers of sub-legal blue crab and immature fish, which are commonly abundant in lagoons, will be retained if the mesh size is too small; conversely, the legal catch of blue crabs will be reduced if the mesh is too large.

In fisheries management, size selectivity curves are important for estimates of incidental mortality, recruitment in yield-per-recruit analysis, and ageand length-based population models (Millar \& Fryer 1999). Notably, size selectivity can be used to evaluate the MLS and the effects of changing escape vent or mesh size regulations on the future productivity of this resource (Treble et al 1998). This study investigates the trap mesh selectivity of five different square mesh $(30,35,40,45 \mathrm{~mm}$ and $50 \mathrm{~mm}$ bar length) size on the escape success of blue crabs.

\section{Material and Methods}

The study was carried out Çamlık Lagoon of Yumurtalı Gulf in the Mediterranean (Figure 1). A total of 1051 crabs were caught by rectangular baited trap. Experiments were carried out using rectangular shape traps $(70 \times 50 \times 50 \mathrm{~cm})$. A total of 30 traps with 6 different trap groups were used in the experiment (Figure 2).

The groups were consist of a smaller mesh size $(10 \mathrm{~mm})$ control traps and the rest were experimental traps which mesh sizes were $30,35,40,45$ and $50 \mathrm{~mm}$ bar length square mesh. The setting of the traps were made randomly and baited with 4 whole sardines, Sardina pilchardus.

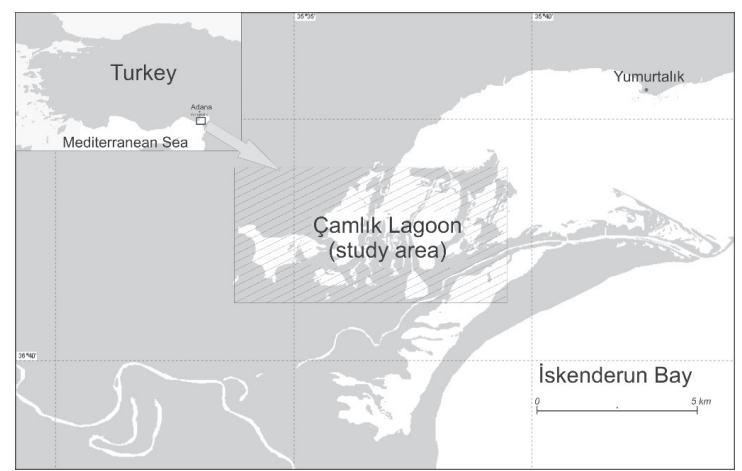

Figure 1- Study area (Çamlık Lagoon of Yumurtalık Gulf)

Şekil 1-Araştırma sahası (Yumurtalık körfezi-Çamlık Lagünü) 


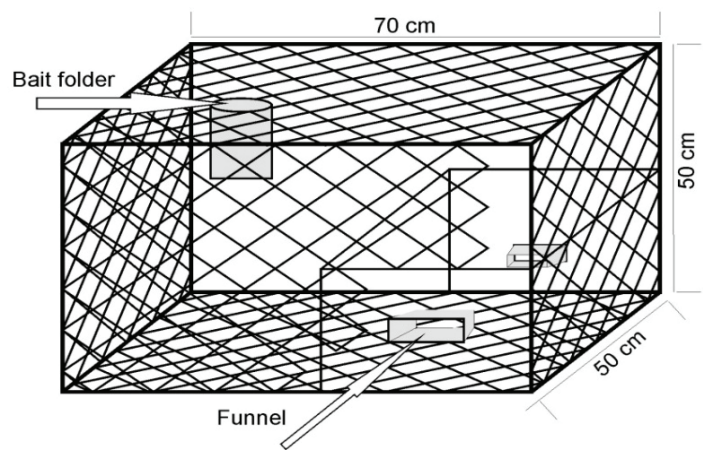

Figure 2- Rectangular baited trap

Şekil 2- Dikdörtgen şekilli yemli tuzak

The relationship between size and escape probability was investigated using SELECT methods for selectivity experiments developed for analyzing data from selectivity experiments using comparative catches from 2 or more gears especially for the trap selectivity (Millar 1992; Millar \& Fryer 1999). Size frequency was established by classifying the $\mathrm{CW}$ data into classes of $0.5 \mathrm{~cm}$ each. Here SELECT model was used to fit data to the most commonly used logistic function

$$
r(l)=\frac{\exp (a+b l)}{1+(\exp (a+b l))}
$$

Where; $r(1)$ is the probability that a fish of size 1 will be retained, and parameters $\mathrm{a}$ and $\mathrm{b}$ are estimated, with $\mathrm{a}<0$ and $\mathrm{b}>0$. The length at $50 \%$ retention, 150 , is given by:

$$
l 50=\frac{-a}{b}
$$

Split parameter, $\mathrm{p}$, is also a model of SELECT method. The parameter described as relative fishing power and can be split into: (i) relative fishing effort, and; (ii) relative fishing efficiency of the trap types, given that all crabs captured were measured.

Selectivity parameters were estimated for each trial using the "SOLVER" tool in MS-Excel (Tokai 1997). Results of the selection analysis for each class are presented in Table I, giving the estimated parameters $a$ and $b$ of the fitted logistic curves for all individual trials, and pooled curves with the respective variance-covariance matrix Ri, which estimates within-variation in the parameters. Friedmans ANOVA non-parametric statistic tests were used to examine differences between the pooled $\mathrm{CW}$ frequencies of the tested mesh sizes.

\section{Results and Discussion}

The number of specimens caught in the traps was 1051 blue crabs during the selectivity study, with sizes ranging from 6 to $16 \mathrm{~cm}$ carapace width $(\mathrm{CW})$. The total numbers of the blue crabs caught by the traps; control, $30 \mathrm{~mm}, 35 \mathrm{~mm}, 40 \mathrm{~mm}, 45 \mathrm{~mm}$ and $50 \mathrm{~mm}$ bar lengths were 259, 238, 200, 171, 139 and 44 respectively (Table 1 ).

Mean $\mathrm{L}_{50}$ and SR of blue crabs were found as $8.47 \mathrm{~cm}$ and $0.85 \mathrm{~cm}$ for $30 \mathrm{~mm}$ bar length, 9.31 $\mathrm{cm}$ and $0.39 \mathrm{~cm}$ for $35 \mathrm{~mm}$ bar length, $10.40 \mathrm{~cm}$ and $0.31 \mathrm{~cm}$ for $40 \mathrm{~mm}$ bar length, $11.72 \mathrm{~cm}$ and $0.81 \mathrm{~cm}$ for $45 \mathrm{~mm}$ bar length, $13.17 \mathrm{~cm}$ and 0.89 $\mathrm{cm}$ for $50 \mathrm{~mm}$ bar length respectively. When the $\mathrm{L}_{50}$ is compared to those of other traps it can be seen that $50 \mathrm{~mm}$ bar length traps increases the $\mathrm{L}_{50}$ for blue crap. Table 2 showed parameters estimates of SELECT model of each mesh size for pooled blue crab, data escaping through five different square mesh sizes (30, 35, 40, 45, and $50 \mathrm{~mm}$ bar length).

Table1- Number of blue crabs (Callinectes sapidus), caught in traps. Carapace width $(\mathrm{CW})$, control sampling (CS)

Çizelge 1- Tuzaklarla yakalanan mavi yengeçlerin (Callinectes sapidus) saylsı. Karapaks genişliği (CW), kontrol örnekleri (CS)

\begin{tabular}{ccccccc}
\hline$C W$ & \multicolumn{7}{c}{ Trap mesh size $(\mathrm{mm})$} \\
\cline { 2 - 7 }$(\mathrm{cm})$ & $C S$ & 30 & 35 & 40 & 45 & 50 \\
6 & 1 & 0 & 0 & 0 & 0 & 0 \\
7 & 2 & 0 & 0 & 0 & 0 & 0 \\
8 & 9 & 2 & 0 & 0 & 0 & 0 \\
9 & 16 & 13 & 2 & 0 & 0 & 0 \\
10 & 40 & 36 & 35 & 2 & 0 & 0 \\
11 & 50 & 48 & 45 & 52 & 11 & 0 \\
12 & 69 & 64 & 59 & 58 & 58 & 4 \\
13 & 57 & 60 & 40 & 43 & 55 & 25 \\
14 & 9 & 8 & 14 & 13 & 9 & 8 \\
15 & 5 & 5 & 4 & 2 & 6 & 6 \\
16 & 1 & 2 & 1 & 1 & 0 & 1 \\
\hline Total & 259 & 238 & 200 & 171 & 139 & 44 \\
\hline
\end{tabular}


Table 2- Parameters estimates of select model of each mesh size for pooled blue crab, data escaping through five different square mesh sizes $\left(30,35,40,45\right.$ and $50 \mathrm{~mm}$ bar length). Fifty percent retention lengths $\left(\mathrm{L}_{50}\right)$, selection ranges (SR), regression parameters (a and b) (Pooled)

Çizelge 2- Mavi yengeç için 5 farkl göz açıkliğındaki (30, 35, 40, 45 ve $50 \mathrm{~mm})$ tuzaklara ait tahmin edilen seçicilik parametreleri. \% 50 seçicilik boyu $\left(L_{50}\right)$, seçicilik aralığ $(S R)$, regresyon parametreleri (a ve b)

\begin{tabular}{|c|c|c|c|c|c|c|c|c|c|c|}
\hline \multirow{3}{*}{ Parameters } & \multicolumn{10}{|c|}{ Mesh size $(\mathrm{mm})$} \\
\hline & \multicolumn{2}{|r|}{30} & \multicolumn{2}{|r|}{35} & \multicolumn{2}{|r|}{40} & \multicolumn{2}{|r|}{45} & \multicolumn{2}{|r|}{50} \\
\hline & $P=0.5$ & Pestimates & $P=0.5$ & Pestimates & $P=0.5$ & Pestimates & $P=0.5$ & Pestimates & $P=0.5$ & P estimates \\
\hline$a$ & -22.78 & -21.93 & -37.60 & -52.34 & -102.22 & -72.56 & -43.07 & -22.01 & -35.27 & -32.50 \\
\hline$b$ & 2.69 & 2.59 & 3.96 & 5.62 & 9.93 & 6.98 & 3.79 & 1.88 & 2.70 & 2.47 \\
\hline$p$ & 0.50 & 0.49 & 0.50 & 0.46 & 0.50 & 0.47 & 0.50 & 0.53 & 0.50 & 0.52 \\
\hline $\mathrm{L}_{50}$ & 8.48 & 8.47 & 9.50 & 9.31 & 10.30 & 10.40 & 11.36 & 11.72 & 13.08 & 13.17 \\
\hline$S R$ & 0.82 & 0.85 & 0.56 & 0.39 & 0.22 & 0.31 & 0.58 & 1.17 & 0.81 & 0.89 \\
\hline MLL & -17.65 & -17.60 & -17.75 & -16.65 & -15.10 & -14.50 & -11.52 & -13.51 & -8.02 & -8.05 \\
\hline AIC & 39.30 & 41.20 & 39.50 & 39.29 & 34.21 & 34.99 & 27.05 & 33.01 & 20.04 & 22.11 \\
\hline
\end{tabular}

Figure 3 also demonstrates selection curves of $30,35,40,45$ and $50 \mathrm{~mm}$ bar length square mesh traps for blue crab. To examine the validity of the estimated selectivity curve of each mesh size, carapace widths for $50 \%$ retention in Table 2 were plotted again mesh size in Figure 4. Carapace widths of each retention probability appear to have linear relationship to mesh size (Figure 4). From the carapace widths of $50 \%$ retention for $30,35,40$, 45 and $50 \mathrm{~mm}$ mesh size, the following regression equation was obtained as follow.

$L_{50}=0.2362 M+1.166 \quad\left(r^{2}=0.9892\right)$

Where; $\mathrm{M}$ indicates mesh size in $\mathrm{mm}$.

The biology (Türeli 1999), the weight-length relationship (Atar \& Seçer 2002; Gökçe et al 2006), catching efficiency of different capture methods (Atar et al 2001) and experimental mesh selectivity (Gökçe et al 2007) have already been studied for the blue crab in Turkish waters. However, there was no specific study on blue crab trap mesh selectivity concerned with the Northeastern Mediterranean Sea. The most common measure to protect fish stocks in Turkey, as in many countries, is the minimum mesh size regulation. However, there is no minimum mesh size for trap fisheries according to Turkish Fisheries Regulation (TFG 2012). Regulations differ between countries. According to the Turkish regulation MLS for blue crab is $13 \mathrm{~cm} \mathrm{CW}$. MLS for blue crabs in Delaware, U.S.A. is $12.7 \mathrm{~cm} \mathrm{CW}$ (Guillory \& Prejean 1997). Türeli (1999) reported that the size at first maturity for male blue crabs was $4.48 \mathrm{~cm} \mathrm{CW}$ and for the female $6.05 \mathrm{~cm} \mathrm{CW}$ in İskenderun Bay, Turkey. However, Helser \& Khan (2001) reported that there was no mature individual under $10 \mathrm{~cm} \mathrm{CW}$, and size at 50\% maturity size was approximately $12.5 \mathrm{~cm} \mathrm{CW}$.

Here, we used $13 \mathrm{~cm} \mathrm{CW}$ as a comparison point for the escape success of the blue crab through five different mesh sizes. Guillory \& Prejean (1997) report that unacceptable numbers of sub-legal blue crabs will be retained if the mesh size is too small; conversely, the legal catch of blue crabs will be reduced if the mesh is too large. This statement is confirmed by our results. Using $50 \mathrm{~mm}$ square mesh, more than half the number of crabs at MLS will be retained $\left(\mathrm{L}_{50}=13.08 \mathrm{~cm}\right)$.

\section{Conclusions}

The $50 \mathrm{~mm}$ mesh size of the trap showed relatively better selectivity considering the size at $50 \%$ sexual maturity of blue crab and the high rate of immature escapers. The effects of enhanced mesh size used are considered of great importance in increasing the size selectivity of the gear, and in reducing the 


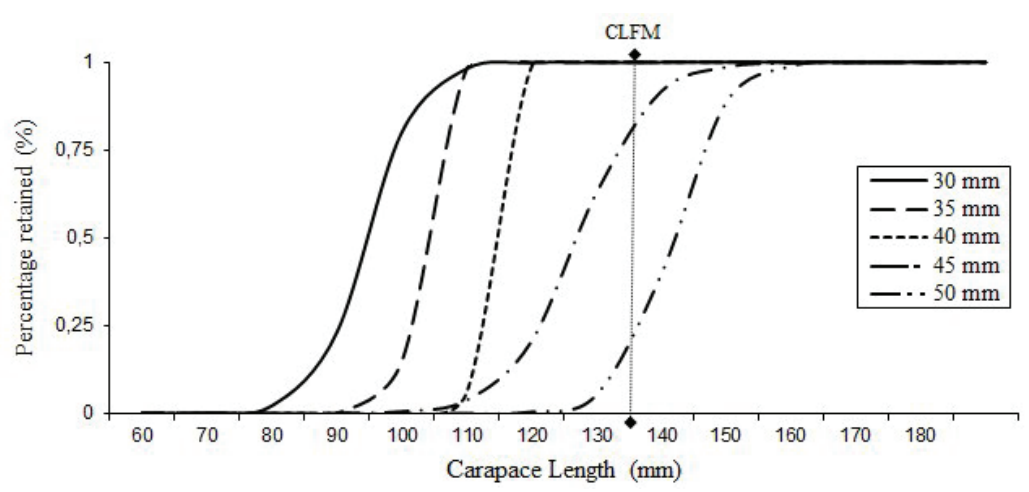

Figure 3- Selection curves for 30, 35, 40, 45 and $50 \mathrm{~mm}$ bar length square mesh traps. The estimated $\mathrm{L}_{50}$ values and carapace width at first maturity (CWFM)

Şekil 3- 30, 35, 40, 45 ve 50 mm kenar uzunluğunda kare gözlü ăga sahip tuzakların seçicilik eğrileri. Tahmin edilen $L_{50}$ değerleri ve ilk üreme karapaks boyu (CWFM)
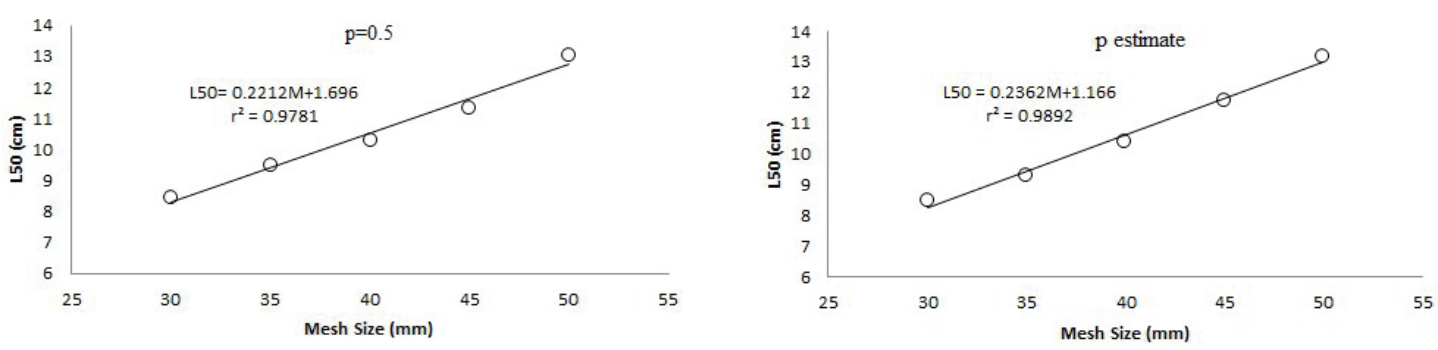

Figure 4- Relationship between mesh size and carapace width of $50 \%$ retention in the $p=0.5$ and $p$ estimate. For the 30, 35, 40, 45 and $50 \mathrm{~mm}$ mesh size, the line indicates regression line for carapace width of $50 \%$ retention

Şekil 4- Karapaks genişliği \% 50 yakalanma oranı ve ă̆ gözü boyutu arasındaki ilişki $(P=0.5$ ve $P$ tahmin edilen). Çizgiler 30, 35, 40, 45 ve $50 \mathrm{~mm}$ ağların karapaks genişliği \% 50 yakalama oran regresyon çizgisini göstermektedir

amount of undersized target species. Therefore, selectivity of the trap is essential to maintaining a sustainable crab fishery. In order to optimize the overall selection performance in such fishery, 50 mm square mesh with baited trap can be used.

\section{Acknowledgements}

The authors would like to thank Prof. Dr. T. Tokai (Tokyo) for providing the program file used in selectivity analysis and also thank technician Erman Tekin and research assistant Oğuz Taşbozan for their efficient and enjoyable field work. This study was supported by the Çukurova University, Department of Scientific Research Projects, Project No: SÜF2005BAP9.

\section{References}

Atar H H, Ölmez M, Bekcan S \& Seçer S (2001). Comparison of three different traps for catching blue crab (Callinectes sapidus Rathbun, 1896) in Beymelek lagoon. Turkish Journal of Veterinary \& Animal Sciences 26: 1145-1150 
Atar H H \& Seçer S (2003). Width/length-weight relationships of the blue crab (Callinectes sapidus Rathbun, 1896) population living in Beymelek Lagoon Lake. Turkish Journal of Veterinary \& Animal Sciences 27: 443-447

Enzenross R, Enzenross L \& Bingel F (1997). Occurrence of blue crab, Callinectes sapidus (Rathbun 1896) (Crustacea, Brachyura) on the Turkish Mediterranean and the adjacent coast and its size distribution in the Bay of İskenderun. Turkish Journal Zoology 21: 113122

Gökçe G, Ergüden D, Sangün L, Çekiç M \& Alagöz S (2006). Width/length-weight relationships of the blue crab (Callinectes sapidus, Rathbun 1896) population living in Çamlık Lagoon lake (Yumurtalık). Pakistan Journal of Biological Science 9: 1460-1464

Gökçe G, Çekiç M, Metin C \& Özbilgin H (2007). Size selectivity of square mesh barriers for Callinectes sapidus (Rathbun, 1896) (Brachyura, Portunidae). Crustaceana 80(3): 277-284

Guillory V \& Prejean P (1997). Blue crab, Callinectes sapidus, trap selectivity studies: mesh size. Marine Fisheries Review 59: 29-31

Helser T E \& Khan D M (2001). Stock assessment of Delaware Bay blue crab (Callinectes sapidus) for 2001. Department of Natural Resources \&
Environmental Control, Delaware Division of Fish and Wildlife Report: 1-41

Millar R B (1992). Estimating the size-selectivity of fishing gear by conditioning on the total catch. The Journal of the American Statistical Association 87: 962-968

Millar R B \& Fryer R J (1999). Estimating the sizeselection curves of towed gears, traps, nets and hooks. Reviews in Fish Biology and Fisheries 9: 89-116

TFG (2012). Turkish Fisheries Regulations, Number 3/1(2012-65): 1-112

Tokai T (1997). Maximum likelihood parameter estimates of a mesh selectivity logistic model through SOLVER on MS-Excel. Bulletin of Japan Fisheries Oceanography 61: 288-298

Treble R J, Millar R B \& Walker T I (1998). Size-selectivity of lobster pots with escape-gaps: application of the SELECT method to the southern rock lobster (Jasus edwardsii) fishery in Victoria, Australia. Fisheries Research 34: 289-305

Tureli C (1999). Aspects of the biology of blue crab (Callinectes sapidus Rathbun, 1896) in İskenderun Bay (Turkey). PhD thesis, Department of Fisheries Institute of Natural and Applied Sciences University of Çukurova. (Unpublished) 